Biol. Stud. 2011: 5(3); 19-28 • DOI: https://doi.org/10.30970/sbi.0503.173

www.http://publications.Inu.edu.ua/journals/index.php/biology

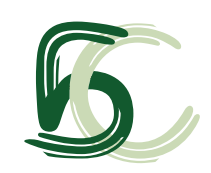

UDC 576.32/36:57.088.3

\title{
EXPRESSION OF RECOMBINANT HUMAN ARGININOSUCCINATE SYNTHETASE IN ESCHERICHIA COLI
}

\author{
O. I. Vovk, Y. A. Rzhepetskyy, H. G. Pereverzeva, O. V. Stasyk \\ Institute of Cell Biology of NAS of Ukraine, 14-16, Drahomanov St., Lviv 79005, Ukraine \\ e-mail: stasyk@cellbiol.Iviv.ua
}

Escherichia coli strain BL21(DE3)/pET42a/ASS - an efficient producer of recombinant human argininosuccinate synthetase (rhASS) - was constructed, and preparations of purified rhASS were obtained using His-tag affinity chromatography. The effect of specific inhibitor, $\alpha$-methyl-DL-aspartate, and nitric oxide donor, sodium nitroprusside, on the ASS specific activity was evaluated with purified rhASS protein and in mouse liver lysates. The developed expression platform is a useful tool in search for new ASS inhibitors efficient under in vitro and in vivo conditions.

Keywords: argininosuccinate synthetase, arginine biosynthesis, recombinant protein expression, affinity purification.

\section{INTRODUCTION}

Argininosuccinate synthetase (ASS; L-citrulline, L-aspartate ligase; EC 6.3.4.5) plays an important physiological role as a rate-limiting enzyme of urea cycle and biosynthesis of arginine, a semi-essential amino acid in humans [12]. Consequently, ASS affects arginine-dependent synthesis of nitric oxide, polyamines, proline and glutamate [14]. The inherited deficiency in ASS causes citrullinemia, an autosomal recessive disorder, characterized by the elevated levels of blood citrulline and ammonia, which often results in hyperammonemic coma and early neonatal death [11]. In turn, some types of tumors, such as melanomas, renal and prostate carcinomas, mesotheliomas, some hepatocellular carcinomas exhibit downregulation of ASS expression leading to the inability to synthesize endogenous arginine, and to intrinsic dependence of such tumors on extracellular arginine supply (known as „arginine auxotrophy”) [6, 7]. Enzymatic arginine deprivation is a novel approach to target proliferation of tumors which lack ASS expression [8]. Several phase I/II trials with arginine-degrading pegylated bacterial arginine deiminase and human arginase I have shown clinical benefits in suppressing tumor growth and low toxicity in patients with ASS-negative tumors [5, 6].

It was also observed that arginine deprivation can trigger upregulation of ASS expression in certain tumors, which, in turn, can lead to in vivo drug resistance $[6,8,12]$. In such cases, application of low molecular weight ASS inhibitors may be desirable to 
improve therapeutic outcome. However, few ASS inhibitors are known from the literature $[9,18]$. The aim of this work was to construct the producer of recombinant human ASS (rhASS) in E. coli and to evaluate efficacy of the potential ASS inhibitors using purified enzyme preparations.

\section{MATERIALS AND METHODS}

Construction of expression plasmid. cDNA for the human ASS gene was isolated from human hepatocellular carcinoma HepG2 cell line which is characterized by high ASS expression [2]. Amplification of the ASS full-length cDNA was performed using oligonucleotide primers ASS-f (5'-CCGGATCCGATGACGATGACAAGTCCAGCAAAGGCTCCGTGGTT-3') and ASS-r (5'-GCGCGGCCGCTTACTTAGTTACTATTTGGCAGTGACCTTGCT-3'), which carried BamHI and Notl restriction sites, respectively. The corresponding PCR resulted in the amplification of a single DNA product of the predicted for human ASS size (1280 base pairs). The isolated DNA fragment was treated with the appropriate restriction endonucleases and ligated into the $p E T-42 a$ vector (Novagen), under control of lac operator regulated T7 promoter, induced by IPTG (isopropyl 1-thio-beta-D-galactopyranoside). pET-42a vector also contains adjacent to T7 promoter sequences, encoding GST- and (His) $)_{6}$-tags for affinity purification, and ASS coding region was cloned as their C-terminal fusion (Fig. 1). The resulting vector pET$42 \mathrm{a} / \mathrm{ASS}$ was amplified in E. coli DH5 $\alpha$ cells. The correctness of the constructed vector was confirmed by sequencing (Genomed, Poland). pET-42a/ASS was transformed into BL21(DE3) E. coli cells to achieve IPTG-induced rhASS expression.

Expression of rhASS in E. coli and purification of the enzyme using affinity chromatography. BL21 cells harboring the pET-42a/ASS plasmid were grown in lysogeny broth (LB) medium (1.0\% Tryptone, $0.5 \%$ Yeast Extract, 1.0\% Sodium Chloride, $\mathrm{pH}$ 7.0) containing $30 \mathrm{mg} / \mathrm{ml}$ of kanamycin as selective marker overnight at $37^{\circ} \mathrm{C}$. A total of $5 \mathrm{ml}$ of this overnight culture were inoculated into $250 \mathrm{ml}$ of fresh LB medium containing identical antibiotic concentration. Recombinant protein expression was induced by adding IPTG to a final concentration of $1 \mathrm{mM}$, when the optical density of the culture reached $0.5-0.6 \mathrm{OD}_{600}$ and temperature was lowered to $26-29^{\circ} \mathrm{C}$ for 4 hours. Bacterial cells were harvested by centrifugation at $3,500 \mathrm{rpm}$ for $20 \mathrm{~min}$ at $4^{\circ} \mathrm{C}$, washed with cold saline solution and pellets were stored at $-70^{\circ} \mathrm{C}$ until use. For ASS purification, bacterial pellets were resuspended in ice-cold (volume ratio 1:10) extraction buffer $(20 \mathrm{mM}$ Tris- $\mathrm{Cl}(\mathrm{pH}$ 8.0), $300 \mathrm{mM} \mathrm{NaCl}, 5 \mathrm{mM}$ imidazole) which was supplemented with lysozyme (1 mg/ml), and a mixture of protease inhibitors $(5 \mathrm{mM}$ benzamidine, $1 \mathrm{mg} / \mathrm{ml}$ pepstatin, $10 \mathrm{mg} / \mathrm{ml}$ leupeptin, $1 \mathrm{mM}$ Na orthovanadate, $10 \mathrm{mg} / \mathrm{ml}$ aprotinin, $1 \mathrm{mM}$ phenylmethylsulfonyl fluoride). To reduce the viscosity, lysate was passed through the syringe needle several times. After incubation for $20 \mathrm{~min}$, samples were sonicated $(3 \times 10 \mathrm{sec}$ on ice with $20 \mathrm{sec}$ intervals) and centrifuged at $15,000 \mathrm{~g}$ for $30 \mathrm{~min}$ at $4^{\circ} \mathrm{C}$. Pre-equilibrated in extraction buffer nickel-nitrilotriacetic acid (Ni-NTA) Superflow agarose (Qiagen) or glutathione (GSH) - sepharose 4B (Pharmacia Biotech) was added to the supernatants and incubated with gentle rotation at $4^{\circ} \mathrm{C}$ overnight. Purified proteins were collected in elution buffer containing $20 \mathrm{mM}$ Tris, $300 \mathrm{mM} \mathrm{NaCl}, 250 \mathrm{mM}$ imidazole (pH 8.0), dialyzed against $50 \mathrm{mM}$ Tris, $150 \mathrm{mM} \mathrm{NaCl}, 50 \%$ glycerol overnight and stored at $-20^{\circ} \mathrm{C}$ until use. Sodium dodecyl sulfate polyacrylamide gel electrophoresis (SDS-PAGE) and Western blot analysis were carried out to estimate the protein purity. Protein concentration was determined according to Peterson's method [16].

ISSN 1996-4536 • Біологічні Студії / Studia Biologica • 2011 • Том 5/№3 • С. 19-28 
SDS-PAGE and Western blot analysis. For Western blot analysis proteins were separated on 10\% SDS-PAGE [15], and transferred onto a polyvinylidene difluoride membrane (Millipore) [19]. The membranes were blocked in $5 \%$ non-fat dried milk in PBS containing $0.05 \%$ Tween-20 and immunoblotted with primary monoclonal antibodies to ASS (BD Transduction Laboratories) or to His-Tag (Millipore). Secondary goat horseradish peroxidase-conjugated anti-mouse antibody (Millipore) and an enhanced chemiluminescence's system („Amersham Biosciences”, USA) were used for the detection of immunoreactive protein bands.

Assay for enzymatic activity of argininosuccinate synthetase. ASS activity was assessed based on the accumulation of the product pyrophosphate as inorganic phosphate [13], following cleavage with pyrophosphatase (Sigma). ASS (1-2 $\mu \mathrm{g}$ of purified protein) was added to the reaction buffer $(20 \mathrm{mM}$ Tris- $\mathrm{HCl}(\mathrm{pH} 8.0), 2 \mathrm{mM}$ ATP, $2 \mathrm{mM}$ citrulline, $2 \mathrm{mM}$ aspartic acid, $6 \mathrm{mM} \mathrm{MgCl}_{2}, 20 \mathrm{mM} \mathrm{KCl}$, and 0.1 units of pyrophosphatase) to a final volume of $100 \mu$ l. The samples were incubated at $37^{\circ} \mathrm{C}$ in 96 -well plates, and the reactions were terminated after $30 \mathrm{~min}$ by the addition of an equal volume of molybdate buffer (10 mM ascorbic acid, $2.5 \mathrm{mM}$ ammonium molybdate, $2 \%$ sulfuric acid) and further incubation at room temperature for $30 \mathrm{~min}$. In the case of mouse liver lysate, the enzymatic reaction was carried out in Eppendorf microtubes (5-10 $\mu \mathrm{g}$ of protein in a probe), and $100 \mu \mathrm{l}$ of $10 \%$ trichloroacetic acid was added to each one, mixed and centrifuged for $10 \mathrm{~min}$ at $12,000 \mathrm{~g} .100 \mu \mathrm{l}$ of supernatants were placed in 96-well plates with further adding of molybdate buffer as described above.

Accumulation of phosphate was determined by measuring the absorbance at 630 $\mathrm{nm}$ on a plate reader (BioTek, Winooski, Vermont, USA), and its concentration was determined by comparison with inorganic phosphate $(\mathrm{Pi})$ standards. Net ASS activity was calculated by subtracting the value at the reaction condition without substrates from that with substrates $[10,13]$.

Inhibition of the ASS catalytic activity by $\alpha$-methyl-DL-aspartate (MDLA) or sodium nitroprusside (SNP) was examined as follows. Increasing amounts of inhibitors were added to ASS fraction in reaction buffer as described in Fig. 4 legends. After incubation at $37^{\circ} \mathrm{C}$ for $60 \mathrm{~min}$, the enzyme activity in the mixtures was estimated by the addition of substrate mixture and further incubation at $37^{\circ} \mathrm{C}$ for $30 \mathrm{~min}$ [17]; finally, the concentration of generated Pi was measured as described above. Specific activity of ASS was expressed as $\mu \mathrm{mol} \mathrm{Pi} / \mathrm{min}$ per mg protein.

Statistics. Each experiment was performed at least three times. Significant difference from the control was compared using Student's $t$-test.

\section{RESULTS AND DISCUSSION}

Expression and purification of rhASS protein. The human ASS gene comprises 16 exons which span 63 kilobases and are mapped to chromosome 9 [22]. Based on cDNA cloning, the predicted protein product consists of 412 amino acids with molecular weight of $46.4 \mathrm{kDa}$. To aid in downstream rhASS purification, we expressed rhASS in E. coli as a fusion protein with both His- and GST- N-terminal tags.

ASS cDNA was isolated by PCR and cloned into pET-42a vector as described in Materials and Methods. The schematic map of the resulting rhASS expression vector, pET-42a/ASS, is shown on Fig. 1. 


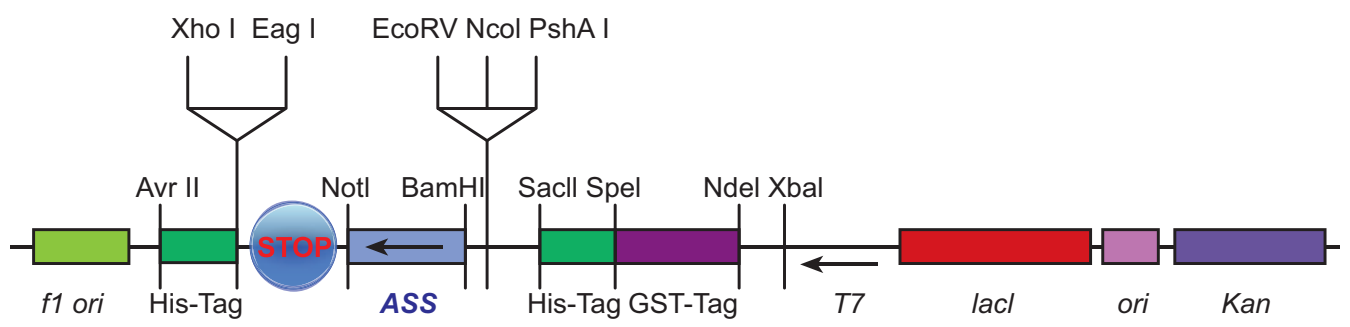

Fig. 1. The scheme of rhASS expression vector pET-42a/ASS (7210 bps). Abbreviations: $f 1$ ori - phage $f 1$ origin of replication for single stranded replication, $T 7$ - specific promoter for RNA polymerase from the $T 7$ bacteriophage, lacl - lac repressor gene, ori - E. coli origin of replication for double stranded replication, Kan - kanamycin resistance gene

Рис. 1. Схема вектора експресії rhASS pET-42a/ASS (7210 пн). Умовні позначення: f1 огі - початок реплікації фрага $f 1$ для одноланцюгової реплікації, $T 7$ - специфічний промотор для RNA полімерази з T7 бактеріофага, lacl - ген репресора lac оперона, ori - початок реплікації E. coli для дволанцюгової реплікації, Кап - ген резистентності до канаміцину

Cultivation conditions were selected to provide maximal ASS expression in E. coli. Namely, cultivation temperature was chosen below $30^{\circ} \mathrm{C}$, and duration of induction of ASS expression with IPTG as 4 hrs. SDS-PAGE of cell lysates with Coomassie Blue staining revealed a predominant protein band of $72 \mathrm{kDa}$ in the IPTG-induced cells, which is a predicted size for the rhASS-fusion protein (Fig. 2, A, lanes 3, 4).

Ni-NTA agarose was used for rhASS (His) 6 -tag affinity purification as described in Materials and Methods. It was shown that $72 \mathrm{kDa}$ dominant band was withdrawn from cell lysates after treatment with Ni-NTA agarose (Fig. 2, A, lines 4, 5), and its main fraction was eluted with $250 \mathrm{mM}$ imidazole (Fig. 2, B). The purity of the eluted protein was approximately $90 \%$ after dialysis and concentration with centrifugal filter devices (Millipore) (Fig. 2, B, lane 3). The yield of 5-10 mg of the partially purified rhASS was obtained per liter of culture broth. Utilization of $\mathrm{GSH}$-sepharose for affinity purification of rhASS via binding to GST-tag produced a lower yield (see Fig. 3, B).

To confirm the identity of the expressed recombinant protein, Western blot analysis was carried out using two different commercial monoclonal antibodies, anti-ASS and anti-His-Tag. With anti-ASS antibody, we revealed the immunoreactive band at $72 \mathrm{kDa}$ in the induced $E$. coli cells, transformed with pET-42a/ASS plasmid, only (Fig. 3, A, lane 4). The lysate of human hepatocellular carcinoma HepG2 cell line was loaded as a positive control (Fig. 3, A, lane 2).

With anti-His-Tag antibody, we observed no immunoreactive signal in untransformed E. coli cells, regardless of IPTG induction (Fig. 3, B, lanes 1, 2), whereas it was present in the lysates of pET-42a/ASS transformant and significantly upregulated upon IPTG treatment (Fig. 3, B, lanes 3 and 4, respectively).

We also confirmed that rhASS can be purified by affinity binding to either Ni-NTA agarose or GSH-sepharose, with higher efficacy in the former (Fig. 3, B, lanes 5, 6, respectively).

Thus, based on our Western blot analysis with anti-ASS and anti-His-Tag monoclonal antibodies, we confirmed expression of rhASS in the constructed $E$. coli producer. However, heterogenity of the recombinant protein product was also evident, probably due to the inefficient transcription of the unmodified heterologous gene in $E$. coli host

ISSN 1996-4536 • Біологічні Студії / Studia Biologica • 2011 • Том 5/№3 • С. 19-28 
(Fig. 3, B). Our attempts to overcome this problem by manipulating with media and cultivation conditions, as well as by expressing pET-42a/ASS in alternative $E$. coli host strains were not successful (data not shown).

A

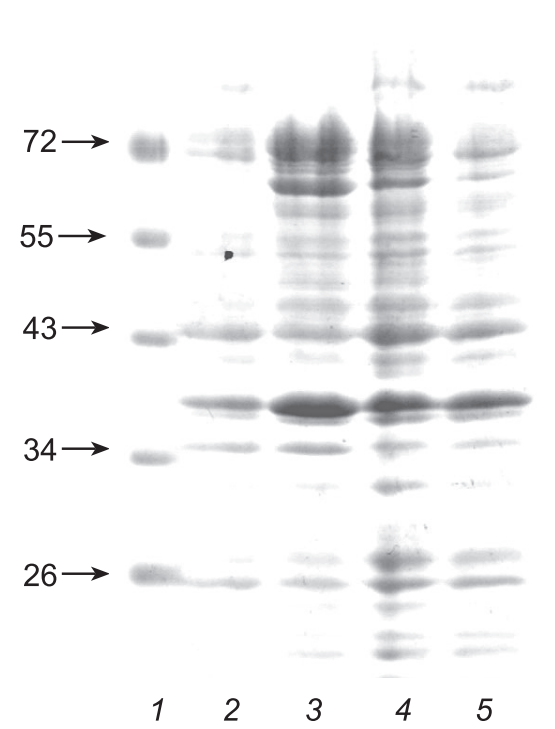

B

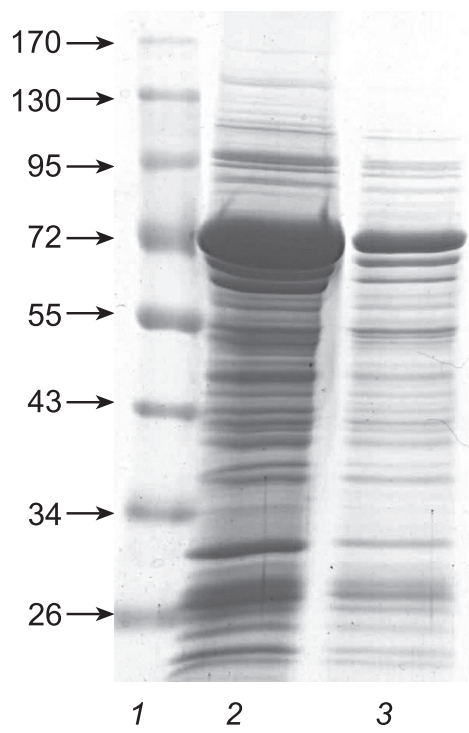

Fig. 2. SDS-PAGE analysis of lysates of rhASS-expressing $E$. coli strain $(A)$ and of the affinity-purified protein $(B)$.

A: lane 1 - protein molecular weight markers (PM); lanes 2, 3-pellet from $0.5 \mathrm{ml}$ lysate of uninduced (2) and induced (3) with $1 \mathrm{mM}$ IPTG E. coli pET-42a/ASS transformed cells, respectively; lanes 4, 5 supernatant of sonicated lysate of rhASS producer before (4) and after (5) incubation with Ni-NTA agarose, respectively, $25 \mu$ were loaded per lane;

$B$ : lane 1 - PM; lane 2 - protein eluted from Ni-NTA agarose with $250 \mathrm{mM}$ imidazole, $10 \mu \mathrm{l}$; lane 3 concentrated protein after dialysis, $5 \mu \mathrm{l}$ (see M\&M for details)

Рис. 2. Електрофоретичний аналіз лізатів $E$. coli продуцента rhASS $(A)$ та афрінно очищеного білка $(B)$ у поліакриламідному гелі за наявності SDS.

A: доріжка 1 - білкові маркери (БМ); доріжки 2, 3 - осад з 0,5 мл лізату неіндукованих (2) та індукованих (3) 1 mM-ним IPTG E. coli клітин, трансорормованих рET-42a/ASS, відповідно; доріжки 4, 5 - надосадова рідина лізату підданого дії ультразвуку продуцента rhASS до (4) та після (5) інкубації з Ni-NTA агарозою, відповідно, на лунку нанесено 25 мкл;

B: доріжка 1 - БМ; доріжка 2 - білок, елюйований із Ni-NTA агарози 250 мМ-ним імідазолом, 10 мкл; доріжка 3 - сконцентрований білок після діалізу, 5 мкл (детальніше див. Матеріали та методи)

Inhibitory effect of MDLA and SNP on ASS activity. In order to verify, whether the expressed $\mathrm{His}_{(6)}$-ASS fusion protein is functional, we assayed its catalytic activity. After detailed analysis of the literature data, we found that for the measurement of ASS specific activity different methods were applied. In particular, for investigation of citrullinemia type I genetic variants by in vitro studies, C. Berning et al. [1] determined activity of wild-type and mutant ASS proteins in nickel agarose elution samples, by measuring the formation of argininosuccinate from aspartate, citrulline, and ATP using newly developed assay tandem mass spectrometry. Another accepted method to assay ASS activity is based on the conversion of radiolabeled aspartate to argininosuccinate [18, 22]. In the work of G. Hao and co-authors [13], ASS activity was assessed based on the 
accumulation of its product, pyrophosphate. However, the ASS activity was represented as percentage of a control value. This method, with modifications described in Materials and Methods section, was utilized in current study.

A

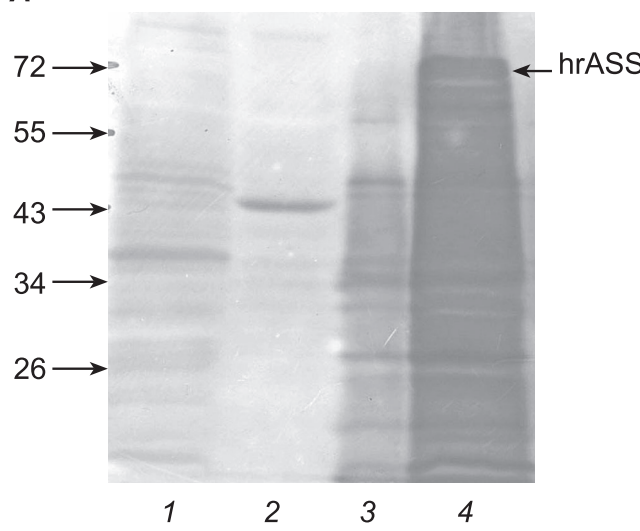

Anti-ASS antibodies

$B$

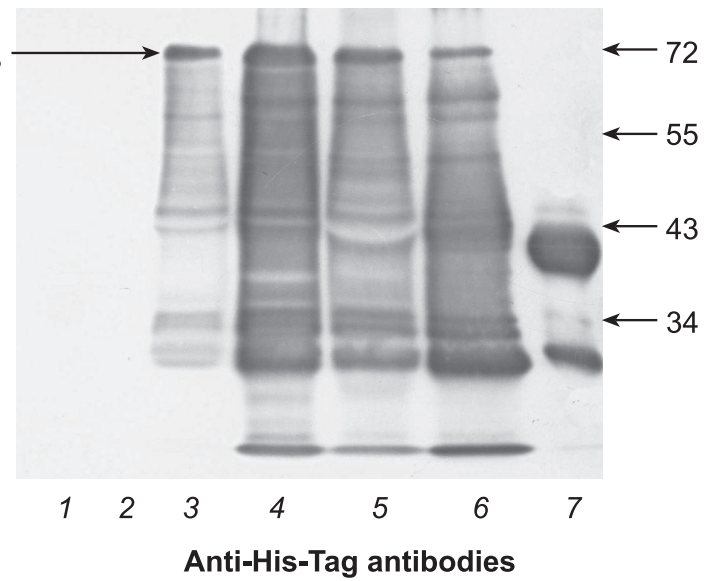

Fig. 3. Western blot analysis of ASS expression and affinity purification.

$A$ - visualization of rhASS protein with anti-ASS antibodies: lane 1 - lysate of untransformed E. coli BL21 cells, lane 2 - lysate of HepG2 human hepatocarcinoma cells (the source of the ASS gene), lanes 3, 4- lysates of uninduced (3) and induced (4) with 1 mM IPTG E. coli cells transformed with $\mathrm{pET}-42 \mathrm{a} / \mathrm{ASS}$;

$B$ - visualization of rhASS protein with anti-His-Tag antibodies: lanes 1,2 - lysates of uninduced (1) and induced (2) with IPTG cells of $E$. coli recipient strain BL21; lanes 3, 4- lysates of rhASS producer, correspond to lanes 3, 4 Fig. 3, A above; lanes 5, 6- Ni-NTA agarose (5) and GSH- sepharose (6) beads after incubation with supernatant of sonicated lysate of rhASS producer; lane 7 preparation of (His) $)_{6}$-tagged recombinant human arginase I

Рис. 3. Вестерн-блот аналіз експресії та афінного очищення ASS.

A - візуалізація rhASS білка за допомогою анти-ASS антитіл: доріжка 1 - лізат нетрансформованих E. coli BL21 клітин; доріжка 2 - лізат клітин гепатокарциноми людини лінії HepG2 (джерело виділення гена ASS); доріжки 3, 4 - лізати неіндукованих (3) та індукованих (4) 1 mM-ним IPTG E. coli клітин, трансформованих плазмідою pET-42a/ASS;

$B$ - візуалізація rhASS білка за допомогою анти-His-Tag антитіл: доріжки 1, 2 - лізати неіндукованих (1) та індукованих (2) 1 mM-ним IPTG реципієнтних клітин BL21; доріжки 3, 4 - лізати rhASS продуцента, відповідають доріжкам 3,4 на рис. 3, A; доріжки 5, 6 - Ni-NTA агароза (5) та GSH-сефароза (6) після інкубації з надосадова рідина лізату підданого дії ультразвуку rhASS продуцента; доріжка 7 - препарат (His) 6 -tag рекомбінантної аргінази людини

We found that purified preparations of rhASS exhibit specific activity around $30 \mu \mathrm{mol} \times \mathrm{min}^{-1} \times \mathrm{mg}^{-1}$ protein, whereas the ASS activity in mouse liver lysate, used as a positive control, was almost twice as high. A preheated sample $\left(100^{\circ} \mathrm{C}, 10 \mathrm{~min}\right)$ of rhASS protein was used as a negative control and exhibited no detectable ASS activity.

An aspartate analogue, $\alpha$-methyl-DL-aspartic acid (MDLA), has been previously shown to be a specific inhibitor of ASS from a variety of tissues [9, 18]. For instance, to elucidate the effect of the down-regulation of ASS activity on nitric oxide (NO) production in bovine aortic endothelial cells, MDLA was used at concentration of $10 \mathrm{mM}$ [18] or $8 \mathrm{mM}$ [9]. Experimental procedure of Guerreiro et al [10], in which $1 \mathrm{mM}$ MDLA was added into culture medium of human embryonic kidney 293 cells, or administered to spontaneous hypertensive rats at $1 \mathrm{mmol} / \mathrm{kg}$, revealed that ASS is a functional target for

ISSN 1996-4536 • Біологічні Студії / Studia Biologica • 2011 • Том 5/№3 • С. 19-28 
a snake venom anti-hypertensive peptide. Therefore, MDLA is an ASS inhibitor in low $\mathrm{mM}$ range, which, however, may be too high to be used in humans as auxiliary agent of anticancer enzymotherapy (see Introduction).

Although arginine deprivation therapy, as an anticancer strategy, has been investigated for several decades [12], it is only recently was shown encouraging activity in patients with specific tumor types [21]. However, prolonged arginine starvation in human may cause vasoconstriction and thrombosis due to the deficit of arginine derivative, nitric oxide (NO), as vasodilator and disaggregant [4]. This problem can be overcome via supplementation with exogenous NO-donors in vivo, which could diminish some side effects of arginine deprivation. Sodium nitroprusside (SNP) is one of the most widely used agents for the management of hypertensive emergencies, and has been in clinical use for several decades [20]. Using the BRENDA database of the comprehensive enzyme information system (http://www.brenda-enzymes.org), nitric oxide was also found among the list of potential in vivo ASS inhibitors. Therefore, in this work we evaluated the effect of MDLA, an aspartate analogue, and SNP, an exogenous NO donor, on ASS activity in purified rhASS protein and in mouse liver lysates.

We observed that both analyzed ASS inhibitors elicited concentration-dependent inhibition of ASS (Fig. 4, A, B). The ASS enzymatic activity was completely blocked at
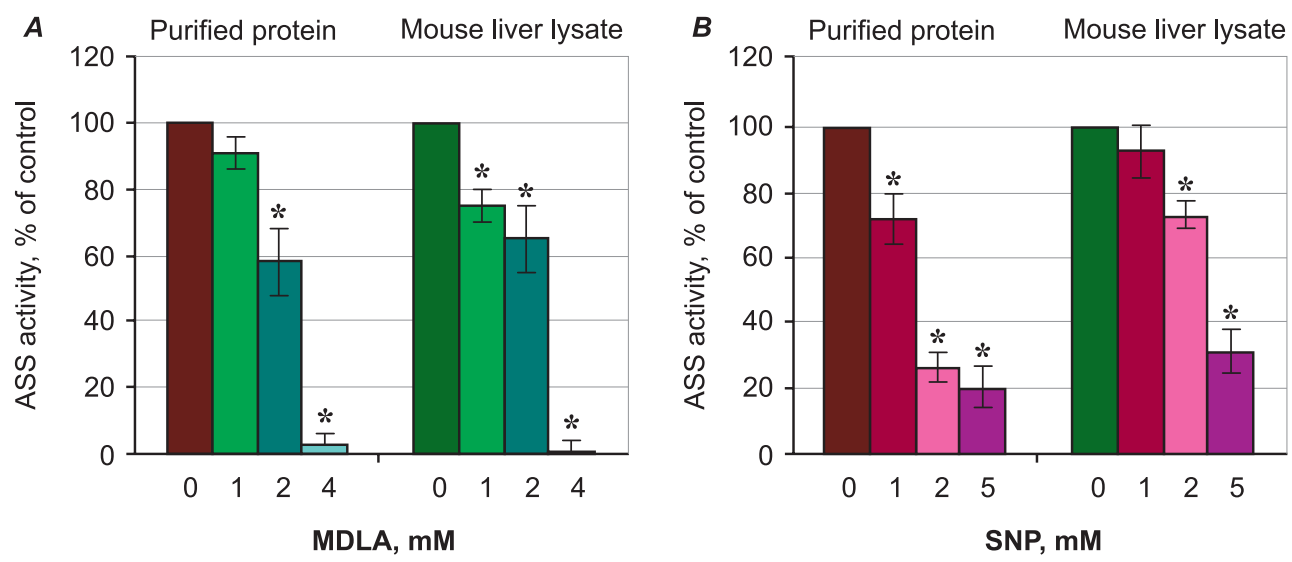

C
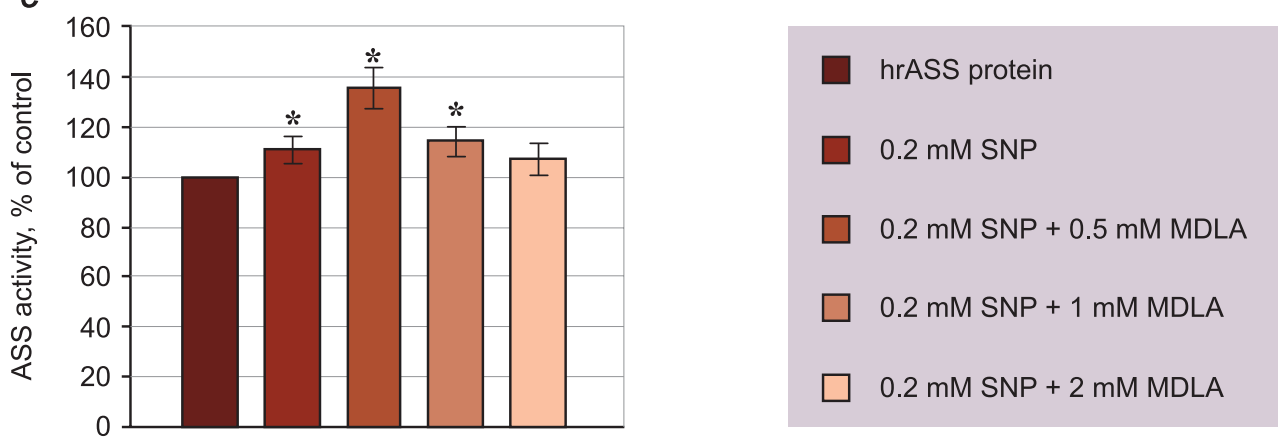

Fig. 4. Effect of MDLA $(A)$, SNP $(B)$ and cumulative effect of MDLA and $0.2 \mathrm{mM}$ SNP $(C)$ on ASS activity, ${ }^{*} \mathrm{p} \leq 0.05$ compared with the untreated hrASS protein

Рис. 4. Вплив MDLA $(A)$, SNP $(B)$ та поєднана дія MDLA і 0,2 mM SNP $(C)$ на активність $A S S,{ }^{*} p \leq 0,05$ порівняно з контролем 
concentration of MDLA $4 \mathrm{mM}$ and higher, similarly for the purified rhASS and in mouse liver lysate (Fig. $4, A$ ). SNP, in a range of $1-5 \mathrm{mM}$, was more effective on purified protein in comparison with mouse liver lysate (Fig. 4, B). Inhibitory concentration index $\left(\mathrm{IC}_{50}\right)$ toward ASS for MDLA was around $2.5 \mathrm{mM}$, for SNP - $1.5 \mathrm{mM}$. The observations on SNP inhibitory effect (Fig. 4, B) are consistent with a mechanism, whereby NO donors reversibly inactivate human ASS by S-nitrosylation of its single cysteine residue [13].

It was previously shown in our laboratory that 0.1-0.2 mM SNP releases exogenous $\mathrm{NO}$ at the level which is close to NO physiological range and may be potentially used as an adjuvant compensatory agent upon arginine deprivation-based therapy for some types of tumors [3]. Therefore, we decided to examine the cumulative effect of SNP at $0.2 \mathrm{mM}$ concentration and low dose of MDLA on ASS activity.

We observed that the combinational treatment of hrASS protein with NO donor and MDLA in low $\mathrm{mM}$ range revealed the opposite effect on its activity (Fig. 4, C) as compared to a separate administration of these inhibitors in a range of 1-5 mM (Fig. 4, $A$, $B)$. Apparently, $0.2 \mathrm{mM}$ SNP compensates the inhibitory influence of the aspartate analogue. The mechanism of this phenomenon requires further investigation.

Taken together, the (His) $)_{6}$ - and GST-tagged recombinant human ASS was expressed in the bacterial system. It was confirmed that (His) -tag does not disturb the ASS enzymatic activity, but allows easy one-step purification procedure by Ni-chelating chromatography. The inhibitory effect of $\alpha$-methyl-DL-aspartate, as well as NO donor, SNP, on the enzyme's activity of mouse liver lysate and purified protein was confirmed. The observed $\mathrm{IC}_{50}$ concentration ranges for effective inhibition by MDLA and SNP were found to be in low millimolar range (Fig. 4, $A, B$ ), a relatively high level from physiological and pharmacological points of view. At lower physiological concentrations, these inhibitors do not provide a desirable ASS inhibition. Nevertheless, the developed scheme will be used in our next studies for in vitro search for more effective ASS inhibitors as components of combinational antitumor enzymotherapy.

1. Berning C., Bieger I., Pauli S. et al. Investigation of Citrullinemia Type I Variants by In Vitro Expression Studies. Human Mutation, 2008; 29(10): 1222-1227.

2. Bobak Y.P., Vynnytska B.O., Kurlishchuk Y.V. et al. Cancer cell sensitivity to arginine deprivation in vitro is not determined by endogenous levels of arginine metabolic enzymes. Cell Biol. Int, 2010; 34(11): 1085-1089.

3. Chen O.I., Lyniv L.S., Igumentseva N.I. et al. Effect of nitric oxide donor on viability of human leukemic cells upon arginine deprivation. Studia Biologica, 2011; 5(2): 17-28.

4. Cheng N.M., Leung Y.C., Lo W.H.: US Patent No. 20050244398. 2005.

5. Cheng P.N., Lam T.L., Lam W.M. et al. Pegylated recombinant human arginase (rhArg-peg$5000 \mathrm{mw}$ ) inhibits the in vitro and in vivo proliferation of human hepatocellular carcinoma through arginine depletion. Cancer Res, 2007; 67: 309-317.

6. Delage B., Fennell D.A., Nicholson L. et al. Arginine deprivation and argininosuccinate synthetase expression in the treatment of cancer. Int. J. Cancer, 2010; 126: 2762-2772.

7. Dillon B.J., Prieto V.G., Curley S.A. et al. Incidence and distribution of argininosuccinate synthetase deficiency in human cancers: a method for identifying cancers sensitive to arginine deprivation. Cancer, 2004; 100: 826-833.

8. Feun L., You M., Wu C.J. et al. Arginine Deprivation as a Targeted Therapy for Cancer. Curr Pharm. Des, 2008; 14(11): 1049-1057.

9. Flam B.R., Eichler D.C., Solomonson L.P. Endothelial nitric oxide production is tightly coupled to the citrulline-NO cycle. Nitric Oxide, 2007; 17: 115-121.

ISSN 1996-4536 • Біологічні Студії / Studia Biologica • 2011 • Том 5/№3 • С. 19-28 
10. Guerreiro J.R., Lameu C., Oliveira E.F. et al. Argininosuccinate Synthetase Is a Functional Target for a Snake Venom Anti-hypertensive Peptide. Role in arginine and nitric oxide production. J. Biol. Chem, 2009; 284(30): 20022-20033.

11. Haberle J., Pauli S., Linnebank M. et al. Structure of the human argininosuccinate synthetase gene and an improved system for molecular diagnostics in patients with classical and mild citrullinemia. Hum. Genet, 2002; 110: 327-333.

12. Haines R.J., Pendleton L.C., Eichler D.C. Argininosuccinate synthase: at the center of arginine metabolism. Int. J. Biochem. Mol. Biol, 2011; 2(1): 8-23.

13. Hao G., Xie L., Gross S. S. Argininosuccinate Synthetase is Reversibly Inactivated by S-Nitrosylation in Vitro and in Vivo. J. Biol. Chem, 2004; 279(35): 36192-36200.

14. Husson A., Brasse-Lagnel C., Fairand A. et al. Argininosuccinate synthetase from the urea cycle to the citrulline-NO cycle. Eur. J. Biochem, 2003; 270: 1887-1899.

15. Laemmli U.K. Cleavage of structural proteins during the assembly of the head of bacteriophage T4. Nature, 1970; 227(259): 680-685.

16. Peterson G.L. A simplification of the protein assay method of Lowry et al. which is more generally applicable. Anal. Biochem, 1977; 83: 346-356.

17. Satoh M., Iwahori T., Sugawara N., Yamazaki M. Liver argininosuccinate synthase binds to bacterial lipopolysaccharides and lipid $A$ and inactivates their biological activities. $\mathbf{J}$. Endotoxin Res, 2006; 12(1): 21-38.

18. Shen L.-J., Beloussow K., Shen W.-C. Accessibility of endothelial and inducible nitric oxide synthase to the intracellular citrulline-arginine regeneration pathway. Biochem. Pharmacology, 2005; 69: 97-104.

19. Towbin H., Staehelin T., Gordon J. Electrophoretic transfer of proteins from polyacrylamide gels to nitrocellulose sheets: procedure and some applications. Biotechnology, 1992; 24: 145-149.

20. Wang P.G., Xian M., Tang X. et al. Nitric oxide donors: chemical activities and biological applications. Chem. Rev, 2002; 102(4): 1091-1134.

21. Wheatley D.N. Controlling cancer by restricting arginine availability - arginine - catabolizing enzymes as anticancer agents. Anticancer Drugs, 2004; 15: 825-833.

22. Xie L., Gross S. S. Argininosuccinate Synthetase Overexpression in Vascular Smooth Muscle Cells Potentiates Immunostimulant-induced NO Production. J. Biol. Chem, 1997; 272(26): 16624-16630.

\title{
ЕКСПРЕСІЯ РЕКОМБІНАНТНОЇ АРГІНІНОСУКЦИНАТСИНТЕТАЗИ ЛЮДИНИ B ESCHERICHIA COLI
}

\author{
О. І. Вовк, Ю. А. Ржепецький, Г. Г. Переверзєва, О. В. Стасик \\ Інститут біології клітини НАН України, вул. Драгоманова, 14-16, Львів 79005, Україна \\ e-mail: stasyk@cellbiol.Iviv.ua
}

Сконструйовано штам Escherichia coli BL21(DE3)/pET42a/ASS - ефективний продуцент рекомбінантної аргініносукцинатсинтетази людини (rhASS) і отримано очищений шляхом His-tag афрінної хроматографії препарат. Досліджено вплив специфічного інгібітора $\alpha$-метил-DL-аспартату, а також донора оксиду азоту нітропрусиду натрію, на питому активність очищеного білка rhASS і активність ASS у лізатах печінки миші. Розроблена система експресії $€$ необхідним інструментом для пошуку нових інгібіторів ASS, ефективних за умов in vitro та in vivo.

Ключові слова: аргініносукцинатсинтетаза, біосинтез аргініну, експресія рекомбінантного білка, афінна хроматографія. 


\title{
ЭКСПРЕССИЯ РЕКОМБИНАНТНОЙ АРГИНИНОСУКЦИНАТСИНТЕТАЗЫ ЧЕЛОВЕКА В ESCHERICHIA COLI
}

\author{
Е. И. Вовк, Ю. А. Ржепецкий, Г. Г. Переверзева, О. В. Стасык
}

Институт биологии клетки НАН Украины, ул. Драгоманова, 14-16, Львов 79005, Украина e-mail: stasyk@cellbiol./viv.ua

Сконструирован штамм Escherichia coli BL21(DE3)/pET42a/ASS - эффективный продуцент рекомбинантной аргининосукцинатсинтетазы человека (rhASS) и получен очищенный путем афффинной His-tag хроматографии препарат. Изучено влияние специфического ингибитора $\alpha$-метил-DL-аспартата, а также донора оксида азота нитропруссида натрия, на удельную активность очищенного белка rhASS и активность ASS в лизатах печени мыши. Разработанная система экспрессии является полезным инструментом для поиска новых ингибиторов ASS, эфффективных в условиях in vitro и in vivo.

Ключевые слова: аргининосукцинатсинтетаза, биосинтез аргинина, экспрессия рекомбинантного белка, афинная хроматография.

Одержано: 09.12.2011 